\title{
PROSES HANDLING BARANG BERBAHAYA DI BANDAR UDARA
}

\author{
Primadi Candra Susanto ${ }^{1}$, Yosi Pahala ${ }^{2}$, Hartono ${ }^{3}$, Sa'Roni $^{4}$ \\ 1,2 Institut Transportasi dan Logistik TRISAKTI, Jakarta, Indonesia \\ ${ }^{3}$ Puslitbang Transportasi Jalan dan Perkeretaapian, Jakarta, Indonesia \\ ${ }^{4}$ Sekolah Tinggi Penerbangan Aviasi, Jakarta, Indonesia \\ e-mail: primstrisakti@gmail.com, yopahala@gmail.com, ambonhartono@gmail.com, \\ ronikonsultan@yahoo.com
}

\begin{tabular}{|c|}
\hline $\begin{array}{l}\text { Penelitian ini bertujuan membahas proses handling barang berbahaya di bandar udara, berdasarkan } \\
\text { IATA (International Air Transport Association) Barang dan atau bahan berbahaya dapat } \\
\text { diklasifikasikan menjadi sembilan kelas yang mempunyai beberapa divisi karena luasnya cakupan } \\
\text { barang berbahaya dan masing-masing diberi kode tertentu sebagai informasi untuk mempermudah } \\
\text { mengindentifikasi bahan atau zat tersebut. Keselamatan pengangkutan barang berbahaya di bandar } \\
\text { udara sangat tergnatung dari kelayakan pengepakan atau handling serta ketepatan pengidentifikasian } \\
\text { terhadap jenis muatan barang berbahaya tersebut. Dangerous Goods adalah zat yang memungkinkan } \\
\text { terjadinya bahaya terhadap kesehatan, keselamatan dan harta milik ketika di angkut dengan pesawat. } \\
\text { Dangerous Goods diatur pada regulasi ICAO annex } 18 \text { - the safe transport of dangerous goods by } \\
\text { air dengan penjelasan pada regulasinya: ICAO DOC } 9284 \text {-AN905 technical Instructions for the safe } \\
\text { transport of dangerous goods by air, ICAO DOC } 9481 \text {-AN928 emergency response guidance for } \\
\text { aircraft incidents involving Dangerous Goods, ICAO DOC } 9375 \text {-AN913 dangerous goods training } \\
\text { programme, di Negara Indonesia ada peraturan tentang Dangerous Goods ini pada UU No.1 Tahun } \\
\text { 2009 tentang penerbangan dengan regulasi turunannya: KM No.16 Tahun } 2009 \text { / CASR part } 92 \text { safe } \\
\text { transport of dangerous goods by air, skep/2765/XII/2010 tata cara pemeriksaan keamanan } \\
\text { penumpang, personel pesawat udara dan barang bawaan pesawat udara dan orang perseorangan, } \\
\text { peraturan Menteri Perhubungan PM } 90 \text { Tahun } 2013 \text { tentang keselamatan pengangkutan barang } \\
\text { berbahaya pada dengan pesawat udara. }\end{array}$ \\
\hline
\end{tabular}




\section{PENDAHULUAN}

Barang berbahaya dapat berbentuk bahan cair, bahan padat atau gas yang dapat membahayakan kesehatan, keselamatan jiwa dan harta benda serta keselamatan dan keamanan penerbangan, yang terdiri dari: a. barang berbahaya yang diklasifikasikan sebagai berikut: 1) bahan peledak (explosives); 2) gas yang dimampatkan, .dicairkan, atau dilarutkan dengan tekanan (compressed gases, liquified or dissolved under pressure); 3) cairan mudah menyala atau terbakar (flammable liquids); 4) bahan atau barang padat mudah menyala atau terbakar (flammable solids); 5) bahan atau barang pengoksidasi (oxidizing substances); 6) bahan atau barang beracun dan mudah menular (toxic and infectious substances); 7) bahan atau barang material radioaktif (radioactive material); 8) bahan atau barang perusak (corrosive substances); dan 9) bahan atau zat berbahaya lainnya (miscellaneous dangerous substances) . b. cairan, aerosol, dan jelly (liquids, aerosols, and gels) dalam jumlah tertentu.

Barang berbahaya dilarang diangkut di pesawat udara, barang berbahaya dilarang diangkut dengan pesawat udara sebagaimana dimaksud dapat dikecualikan, terhadap: a. barang berbahaya yang sesuai petunjuk teknis keselamatan pengangkutan barang berbahaya dengan pesawat udara; dan b. barang berbahaya yang sesuai petunjuk teknis keselamatan pengangkutan barang berbahaya dengan pesawat udara dinyatakan dilarang dan binatang yang terinfeksi, setelah mendapatkan izin khusus.

Petunjuk teknis keselamatan pengangkutan barang berbahaya dengan pesawat udara sebagaimana dimaksud yaitu: a. memperhatikan klasifikasi barang berbahaya yang akan diangkut; b. membatasi jumlah barang berbahaya yang akan diangkut dalam satu kemasan; c. memperhatikan jenis angkutan pesawat udara; d. memenuhi persyaratan : 1) Pengemasan (packing); 2) Pemberian label dan tanda (labelling and marking); 3) Penanganan (handling); 4) Pendokumentasian; dan 5) Penyediaan informasi.

Barang berbahaya yang diangkut dengan pesawat udara dilakukan pengemasan. Pengemasan sebagaimana dimaksud harus menggunakan kemasan dengan ketentuan sebagai berikut: a. memiliki kualitas baik; b. menggunakan bahan dan penutup yang aman untuk mencegah kebocoran yang disebabkan oleh pengangkutan, seperti perubahan suhu, kelembapan, tekanan atau getaran; dan c. memenuhi spesifikasi bahan dan konstruksi. Kemasan yang digunakan untuk barang berbahaya yang bersentuhan langsung harus: a. sesuai dengan isi; dan b. tahan terhadap bahan kimia atau reaksi barang lainnya. Kemasan yang 
akan digunakan untuk barang berbahaya harus dilakukan pengujian oleh instansi pemerintah atau badan hukum yang membidangi pengujian kemasan. Kemasan yang lulus pengujian sebagaimana dimaksud diberikan: a. sertifikat "UN Specification Marking"; atau b. kode "limited quantity". Sertifikat "UN Specification Marking" sebagaimana dimaksud diterbitkan oleh Direktur Jenderal. Kemasan barang berbahaya yang telah memiliki " $U N$ Specification Marking" dari negara lain, tidak perlu dilakukan pengujian. Kemasan yang digunakan untuk barang berbahaya berbentuk bahan cair harus diposisikan berdiri, tanpa ada kebocoran, dan tahan terhadap tekanan. Pengemasan barang berbahaya yang menggunakan kemasan dalam (inner packaging) harus dikemas secara aman dan dilengkapi: a. bahan penahan untuk mengontrol gerakan guna mencegah kerusakan dan kebocoran; dan b. bahan penyerap yang tidak bereaksi terhadap barang berbahaya. Kemasan dilarang digunakan kembali kecuali telah diperiksa dan dinyatakan bebas korosi atau kerusakan lainnya oleh personel penanganan pengangkutan barang berbahaya. Kemasan yang digunakan kembali harus dilakukan pengujian oleh instansi pemerintah atau badan hukum. Hasil pengujian sebagaimana dimaksud pada dikeluarkan rekomendasi untuk mendapat " $U N$ Specification Packaging" jenis rekondisi dan remanufactured yang diterbitkan oleh Direktur Jenderal. Ketentuan lebih lanjut mengenai pengemasan, dan sertifikasi kemasan barang berbahaya diatur dalam petunjuk teknis keselamatan pengangkutan barang berbahaya dengan pesawat udara. Petunjuk teknis keselamatan pengangkutan barang berbahaya dengan pesawat udara sebagaimana dimaksud diatur dalam Peraturan Direktur Jenderal.

\section{LANDASAN TEORI}

Menurut peraturan Direktur Jenderal Perhubungan Udara No. SKEP/77/VI/2005 tentang Persyaratan Teknis Bandar Udara, bandar udara berdasarkan fungsinya dibedakan menjadi tiga bagian, yaitu: 1. Bandar udara yang merupakan simpul yang merupakan simpul dalam jaringan transportasi udara sesuai dengan hierarki fungsinya yaitu Bandar Udara pusat penyebaran dan bukan pusat penyebaran. 2 . Bandar Udara sebagai pintu gerbang kegiatan perekonomian Nasional dan Internasional. 3. Bandar Udara sebagai tempat kegiatan alih moda transportasi.

Bandara atau bandar udara yang juga populer disebut dengan istilah airport merupakan sebuah fasilitas di mana pesawat terbang seperti pesawat udara dan helikopter dapat lepas landas dan mendarat. Suatu bandar udara yang paling sederhana minimal memiliki 
sebuah landasan pacu atau helipad (untuk pendaratan helikopter), sedangkan untuk bandara-bandara besar biasanya dilengkapi berbagai fasilitas lain, baik untuk operator layanan penerbangan maupun bagi penggunanya seperti bangunan terminal dan hanggar. Menurut Annex 14 dari ICAO (International Civil Aviation Organization) : Bandar udara adalah area tertentu di daratan atau perairan (termasuk bangunan, instalasi dan peralatan) yang diperuntukkan baik secara keseluruhan atau sebagian untuk kedatangan, keberangkatan dan pergerakan pesawat.

Menurut Martono (2012), Penerbangan adalah suatu kesatuan sistem yang terdiri atas pemanfaatan wilayah udara, pesawat udara, navigasi penerbangan, keselamatan dan keamanan, lingkungan hidup, serta fasilitas umum lainnya. Sebagai salah satu cabang hukum internasional yang relatif baru, hukum udara mulai berkembang pada awal abad ke-20 setelah munculnya pesawat udara.

Dalam Undang-undang Nomor 1 Tahun 2009 Tentang Penerbangan. Keselamatan Penerbangan adalah suatu keadaan terpenuhinya persyaratan keselamatan dan pemanfaatan wilayah udara, pesawat udara, bandar udara, angkutan udara, navigasi penerbangan, serta fasilitas penunjang dan fasilitas umum lainnya. Keamanan dan keselamatan dalam sebuah penerbangan sipil sangatlah penting dan tergantung pula pada keamanan dari bandar udara yang memberangkatkan pesawat udara tersebut. Mengingat banyaknya ancaman dari tindakan gangguan melawan hukum baik saat pesawat udara di darat maupun di udara. Juga instalasi instalasi pendukung lainnya di sebuah bandar udara

Menurut Benny (2012), Dalam hukum udara, pengaturan terkait pengamanan di bandar udara, yaitu aviation security (AVSEC) yang merupakan sistem keamanan di bandar udara. personel keamanan penerbangan atau AVSEC merupakan personel keamanan penerbangan yang telah (wajib) memiliki lisensi atau surat tanda kecakapan petugas (SKTP) yang diberi tugas dan tanggung jawab di bidang pengamanan penerbangan. Secara internasional, pengamanan penerbangan diatur dalam Annex 17 Security: Safeguarding International Civil Aviation Against Acts of Unlawful Interference dan Document 8973 security manual. Berdasarkan Annex 17 Konvensi Chicago 1944 tersebut, pemeriksaan terhadap penumpang dan barang di bandar udara dilakukan oleh personel keamanan penerbangan. personel keamanan penerbangan memiliki tugas utama untuk memastikan bahwa penumpang dan barang yang masuk ke dalam bandar udara harus diperiksa sesuai dengan prosedur dan memastikan tidak adanya tindakan-tindakan melawan hukum. Terhadap barang yang dibawa oleh pengguna 
jasa transportasi udara, personel keamanan penerbangan harus melakukan pemindaian guna memastikan barang tersebut bukan termasuk barang yang dilarang untuk diangkut atau barang berbahaya (dangerous goods). Penanganan barang berbahaya perlu didukung oleh personel keselamatan penerbangan yang berlisensi sebagai tanda bukti kompetensi yang dimiliki dan ditunjang oleh fasilitas penanganan pengangkutan serta standar produk. Untuk mengurangi resiko kecelakaan yang diakibatkan oleh adanya kesalahan dalam penanganan terhadap barang berbahaya diperlukan standar dan prosedur yang komprehensif dan sesuai dengan regulasi internasional.

\section{METODE PENELITIAN}

Metode penelitian yang digunakan adalah metode penelitian kualitatif melalui studi literatur serta kajian pustaka dari sudut pandang keselamatan penerbangan dan menganalisa suatu rangkaian proses handling barang berbahaya yang diangkut dalam pesawat terbang, dalam studi tersebut akan jabarkan tingkat eksplanasi ketepatan menyusun barang berbahaya dan mengklasifikasi barang berbahaya.

\section{PEMBAHASAN}

Bandar udara sebagai sarana pokok sektor transportasi udara dalam penyelenggaraan penerbangan merupakan tempat untuk pelayanan jasa transportasi udara. Dalam melaksanakan fungsi dan tujuannya maka bandar udara harus ditata secara terpadu guna mewujudkan penyediaan jasa kebandarudaraan. Secara umum, keselamatan dan keamanan penerbangan terdapat di dalam Pasal 44 Konvensi Chicago 1944, yang salah satu poin mengatakan bahwa tujuan dari dibentuknya organisasi penerbangan sipil internasional atau International Civil Aviation Organization (ICAO) salah satunya untuk memperkenalkan atau menyebarluaskan kepada semua negara anggota tentang keselamatan penerbangan khususnya dalam navigasi udara internasional serta mempercepat perkembangan transportasi udara internasional. Kemudian pasal tersebut diperkuat dengan Pasal 28 dalam konvensi yang sama, yang mengatur tentang fasilitas navigasi udara dan sistem standar. Intinya setiap negara peserta konvensi harus mengusahakan fasilitas penerbangan yang sesuai dengan standar internasional semampunya demi keselamatan dan keamanan penerbangan. Berkaitan dengan keselamatan dan keamanan penerbangan, hal yang tidak dapat dipisahkan adalah pengamanan terhadap barang berbahaya (dangerous goods). 
Terhadap barang berbahaya harus dilakukan penanganan khusus dalam pemeriksaan, penempatan dan kemasannya guna menghindari kesalahan dalam penanganan yang menyebabkan kecelakaan pesawat udara. Secara internasional, aturan terkait keamanan barang berbahaya (dangerous goods) secara khusus terdapat dalam Annex 18 The Safe Transport of Dangerous Goods by Air. Dapat disimpulkan bahwa barang berbahaya adalah barang atau bahan yang dapat membahayakan kesehatan, keselamatan, harta benda, dan lingkungan Secara umum, barang berbahaya terbagi atas tiga kategori. Pertama, diperbolehkan untuk diangkut melalui udara. Ini mencakup barang berbahaya yang dapat diangkut dengan persyaratan atau proses tertentu. Kedua, tidak diperbolehkan diangkut melalui udara. Kategori ini mencakup bahan atau barang yang mudah meledak, menimbulkan reaksi berbahaya, menimbulkan api atau perubahan panas yang berbahaya, mengeluarkan emisi beracun, korosif, dan gas atau uap yang mudah terbakar dalam kondisi normal penerbangan. Dan terakhir, barang pengecualian yang dapat diangkut melalui udara. Ini ditujukan untuk bahan atau barang berbahaya yang biasanya dilarang, tapi diberikan pengecualian karena fungsinya.

Pengertian dan Klasifikasi Barang Berbahaya Yang dimaksud dengan barang berbahaya adalah benda atau zat yang memiliki karakter berbahaya terhadap kesehatan, keselamatan, property, dan lingkungan seperti yang tertera atau yang masuk di dalam kualifikasi pada daftar barangbarang berbahaya dari IATA Dangerous Goods Regulation (IATA DGR). Klasifikasi barang berbahaya juga dijabarkan dalam UU No. 1 Tahun 2007 tentang Penerbangan. Klasifikasi IATA DGR mencakup: Kelas 1: Bahan peledak atau dapat meledak (explosives), Kelas 2: Gas, termasuk gas yang dapat terbakar, tidak dapat terbakar, dan beracun Kelas 3: Cairan yang dapat terbakar (alkohol, thinner, bensin, solar, cat), Kelas 4: Bahan padat mudah terbakar, seperti korek api, kalsium karbid, sodium), Kelas 5: Zat oksidasi dan peroksida organic (nitrat, kalsium klorat, pemutih pakaian, hidroperoksida, tert-buty), Kelas 6: Zat beracun dan menular (sianida, bakteri, virus, jamur), Kelas 7: Bahan radioaktif, Kelas 8: Bahan korosif (baterai, cairan air raksa), Kelas 9: Bahan berbahaya lainnya (es kering, material mengandung magnetik, dll.) Selain itu ada juga yang dikenal dengan Hidden Dangerous Goods yaitu kargo umum yang mengandung bahan/zat berbahaya yang tidak tampak. Barang-barang tersebut antara lain: Suku cadang pesawat, Suku cadang kendaraan, Peralatan laboratorium, Peralatan bertenda, 
Peralatan listrik. Pengangkutan Barang Berbahaya dalam Penerbangan Apakah bendabenda yang masuk dalam daftar barang berbahaya bisa diangkut/dibawa dalam penerbangan. Didalam pengangkutannya, barang berbahaya dibagi dalam 4 kategori: Terlarang (Forbidden), yaitu bahan/barang yang dapat meledak, menimbulkan reaksi yang membahayakan, menimbulkan api atau perubahan panas yang membahayakan atau mengeluarkan emisi beracun, korosif, atau gas dan uap yang mudah terbakar pada kondisi normal dalam penerbangan. Dapat diterima (Acceptable), yaitu barang atau bahan yang dapat di angkut dengan mengikuti persyaratan tentang pengangkutan barang berbahaya dalam hal: klasifikasi, kemasan, marka dan label, dan dokumentasi. Dibebaskan (Exempted), yaitu barang atau bahan yang dapat diangkut dengan mendapatkan ijin khusus secara tertulis, antara lain: beberapa jenis bahan radioaktif, binatang terinfeksi, bahan cair yang mempunyai uap beracun yang dapat terhirup, Packing Group I, bahan cair dengan temperatur lebih dari 100 derajat celcius atau bahan padat dengan temperatur lebih dari 240 derajat celcius, dan bahan lain berdasarkan aturan masing-masing Negara. Dikecualikan (Excepted), yaitu: barang berbahaya yang boleh dibawa penumpang atau kru (parfum dan alkohol dalam jumlah terbatas), beberapa bahan dan/atau barang berbahaya yang diangkut melalui pos udara dengan mengikuti persyaratan pengangkutan bahan atau barang berbahaya, bahan/barang operator untuk keperluan pesawat (peralatan penunjang kelaikan pesawat udara, pelayanan penumpang di pesawat seperti parfum, aerosol, minuman beralkohol dan dry ice untuk makanan dan minuman), serta suku cadang pesawat dan peralatan penggantian keperluan lainnya.

Barang berbahaya (Dangerous Goods DG) dapat diangkut dengan aman mempergunakan transportasi udara asalkan prinsip-prinsip tertentu dipatuhi dengan ketat. Regulasi untuk Dangerous Goods disesuaikan dengan pengkategoriannya. Secara umum Dangerous Goods dikelompokkan menjadi dua yaitu non radioative (NRA) dan radioactive (RA). Beberapa organisasi international membuat pengaturan atau regulasi mengenai Dangerous Goods, termasuk pemerintahan Republik Indonesia. United Nation Subcomitee of Expert on the Transportation of Dangerous Goods (SCoETDG) merupakan perwakilan PBB yang mengembangkan dan merekomendasikan prosedur pengangkutan untuk semua jenis barang berbahaya, kecuali material radioactive. Rekomendasi yang dipublikasikan di dalam the recomendations on the transportation of dangerous goods - model 
regulation berlaku untuk seluruh jenis moda transportasi. The International Atomic Energy Agency (IAEA) mengatur pengangkutan material radioaktif. Prosedur dan rekomendasi ini dipublikasikan melalui the regulation for the safety transport of radioactive material. International Civil Aviation Organization (ICAO) mengembangkan regulasi dalam menjamin keselamatan dalam pengangkutan Dangerous Goods yang mempergunakan transportasi udara dengan berbagai tipe pesawat termasuk helikopter, berdasarkan rekomendasi yang dipublikasikan oleh SCoETDG. International Air Transportation Association (IATA) membuat regulasi yang memuat peetunjuk teknis dalam mengidentifikasi, penanganan, kemasan dan dokumentasi yang dibutuhkan dalam pengiriman Dangerous Goods yang mempergunakan moda transportasi udara. Berdasarkan peraturan Menteri Perhubungan nomor PM 90 tahun 2013, tentang keselamatan penganguktan barang berbahaya dengan pesawat udara. Pemerintah Indonesia mengatur operator pesawat udara yang mengoperasikan pesawat udara untuk mengangkut barang berbahaya, orang yang diperbolehkan membawa atau mengirim barang berbahaya dan tata cara pengangkutan barang berbahaya dengan mempergunakan pesawat udara, serta pendidikan dan pelatihan penanganan pengangkutan barang berbahaya dengan pesawat udara. Petunjuk teknis pengangkutan Dangerous Goods yang dipublikasikan IATA berdasarkan petunjuk teknis ICAO, mencakup persyaratan operasional tambahan, yang menyediakan sistem yang harmonis bagi operator untuk menerima dan mengangkut barang berbahaya dengan aman dan efisien. Peraturan tersebut mencakup daftar terperinci dari masingmasing artikel dan zat berdasarkan klasifikasi yang dipublikasikan oleh PBB dari setiap artikel atau zat, dan penerimaan untuk transportasi udara serta kondisi untuk pengangkutannya.

\section{KESIMPULAN}

Pada dasarnya barang berbahaya dapat diangkut dengan pesawat udara, namun harus memenuhi persyaratan sesuai dengan peraturan yang berlaku, termasuk aturan kemasan dan cara pengemasannya, pemberian label, serta penyimpanan dan pemuatannya. Apabila petugas yang menangani barang berbahaya menyimpang dari peraturan, maka dimungkinkan adanya bahaya yang akan mencelakakan manusia, merugikan perusahaan atau merusak fasilitas lain. Oleh karena itu, untuk menjamin keselamatan dan pengamanan serta lancarnya pengangkutan 
barang berbahaya diperlukan penanganan yang sebaik-baiknya dan penuh rasa tanggung jawab. Dangerous goods adalah unsur-unsur zat bahan dan atau barang berbahaya yang sangat peka terhadap suhu udara, tekanan dan getaran serta dapat mengganggu terhadap kesehatan manusia maupun binatang, dapat menggangu serta membahayakan keselamatan penerbangan dan dapat merusakkan peralatan pengangkutan. Barang berbahaya sebagai kargo dapat diangkut dengan pesawat udara dikelompokan menjadi tiga yaitu: Barang berbahaya yang dapat diangkut dengan menggunakan pesawat udara penumpang atau pesawat udara kargo. Barang berbahaya yang hanya dapat diangkut dengan pesawat kargo saja. Barang berbahaya yang tidak boleh diangkut dengan pesawat udara, pengelompokan ini didasarkan pada ciri-ciri atau jenis barang berbahaya ataupun jumlahnya yang akan diangkut dengan pesawat udara.

\section{DAFTAR PUSTAKA}

Benny, Daniel J. 2012, General Aviation Security, Jakarta : CRC Press.

Martono K., Ahmad Sudiro. 2012, Hukum Udara Nasional dan Internasional Publik, Jakarta: PT Raja Grafindo Persada.
Peraturan Direktur Jenderal Perhubungan Udara No. SKEP/77/VI/2005 tentang Persyaratan Teknis Bandar Udara.

Undang-Undang No.1 Tahun 2009, Kementerian Perhubungan, Jakarta.

\section{INTERNET}

https://logicy.wordpress.com/2019/09/17/penga ntar-dangerous-goods/ (diakses pada tanggal 27 September 2020) 